\title{
Effect of two semesters of small group problem-based learning (PBL) on expectations of physician assistant students regarding self, others, and facilitator using the PBL Readiness Questionnaire
}

\author{
Susan Hawkins \\ Chatham University, eghawkins@gmail.com \\ Mark Hertweck \\ Chatham University, Mark.Hertweck@va.gov \\ Anthony Goreczny \\ Chatham University, goreczny@chatham.edu \\ John Laird \\ Chatham University, laird@chatham.edu
}

Follow this and additional works at: https://nsuworks.nova.edu/ijahsp

Part of the Curriculum and Instruction Commons, Educational Methods Commons, and the Medical Education Commons

\section{Recommended Citation}

Hawkins S, Hertweck M, Goreczny A, Laird J. Effect of two semesters of small group problem-based learning (PBL) on expectations of physician assistant students regarding self, others, and facilitator using the PBL Readiness Questionnaire. The Internet Journal of Allied Health Sciences and Practice. 2016 Jan 01;14(1), Article 5.

This Manuscript is brought to you for free and open access by the College of Health Care Sciences at NSUWorks. It has been accepted for inclusion in Internet Journal of Allied Health Sciences and Practice by an authorized editor of NSUWorks. For more information, please contact nsuworks@nova.edu. 


\title{
Effect of two semesters of small group problem-based learning (PBL) on expectations of physician assistant students regarding self, others, and facilitator using the PBL Readiness Questionnaire
}

\begin{abstract}
Purpose: The purpose of this study was to assess changes in expectations and perceptions among physician assistant (PA) program matriculants regarding small group problem-based learning (PBL) from the beginning to the end of the first didactic year. Some of the stress experienced by students entering health science professional programs using PBL may be due to lack of awareness of the goals and norms of PBL which differ from those of traditional lecture-based curricula. A change in student expectations as a result of participation in PBL would indicate that these goals and norms can be learned through participation. Methods: The authors developed the PBL Readiness Questionnaire, a 71-item 10-point Likert scale regarding student expectations of the PBL experience regarding self, others and the facilitator. Questionnaire items were developed using data from a student survey as well as literature on characteristics associated with successful performance in a PBL setting. The questionnaire was administered to 60 PA students at the beginning of the first year fall semester and again at the end of the first year spring semester. Results: Analysis revealed a significant change from pre to posttest on total score as well as on the subscales of Expectations of Self and Expectations of Facilitators. The subscale of Expectations of Others approached significance. Conclusions: The change in Expectations of Facilitator may reflect the different role of facilitator vs. lecturer. Facilitators challenge physician assistant students with questions rather than providing information. The change in Expectations of Self could indicate that physician assistant students do not have accurate expectations of their own role in this type of group setting, and the experience of participating in PBL may positively affect their expectations. An area for future study would be a psychometric analysis of the questionnaire items in order to refine the tool and ascertain the reliability and validity of items and subscales.
\end{abstract}

\section{Author Bio(s)}

- Susan R. Hawkins, MSEd, PA-C, is an Associate Professor in the Physician Assistant Studies Program at Chatham University.

- Mark L. Hertweck, MA, PA-C, is an Associate Professor in the Physician Assistant Studies Program at Chatham University.

- Anthony J. Goreczny, PhD, is a Professor in the Counseling Psychology Program at Chatham University.

- John Laird, ND, is an Associate Professor in the Physician Assistant Studies Program at Chatham University. 


\title{
IJAHSP \\ The Internet Joưnal of Allied Health Sciences and Practice
}

Dedicated to allied health professional practice and education

Vol. 14 No. 1 ISSN 1540-580X

\section{Effect of Two Semesters of Small Group Problem-Based Learning (PBL) On Expectations of Physician Assistant Students Regarding Self, Others, and Facilitator Using the PBL Readiness Questionnaire}

\author{
Susan Hawkins, MSEd, PA-C \\ Mark Hertweck, MA, PA-C \\ Anthony Goreczny, PhD \\ John Laird, ND \\ Chatham University \\ United States
}

\begin{abstract}
Purpose: The purpose of this study was to assess changes in expectations and perceptions among physician assistant (PA) program matriculants regarding small group problem-based learning $(\mathrm{PBL})$ from the beginning to the end of the first didactic year. Some of the stress experienced by students entering health science professional programs using PBL may be due to lack of awareness of the goals and norms of PBL which differ from those of traditional lecture-based curricula. A change in student expectations as a result of participation in PBL would indicate that these goals and norms can be learned through participation. Methods: The authors developed the PBL Readiness Questionnaire, a 71-item 10-point Likert scale regarding student expectations of the PBL experience regarding self, others and the facilitator. Questionnaire items were developed using data from a student survey as well as literature on characteristics associated with successful performance in a PBL setting. The questionnaire was administered to 60 PA students at the beginning of the first year fall semester and again at the end of the first year spring semester. Results: Analysis revealed a significant change from pre to posttest on total score as well as on the subscales of Expectations of Self and Expectations of Facilitators. The subscale of Expectations of Others approached significance. Conclusions: The change in Expectations of Facilitator may reflect the different role of facilitator vs. lecturer. Facilitators challenge physician assistant students with questions rather than providing information. The change in Expectations of Self could indicate that physician assistant students do not have accurate expectations of their own role in this type of group setting, and the experience of participating in PBL may positively affect their expectations. An area for future study would be a psychometric analysis of the questionnaire items in order to refine the tool and ascertain the reliability and validity of items and subscales.
\end{abstract}

\section{INTRODUCTION}

Students entering health science programs that utilize small group problem-based learning (PBL) encounter an environment that is novel and stressful to them. ${ }^{1}$ Some of the stress results from a lack of awareness of the goals and norms of PBL. The goals of PBL are to provide a framework for acquiring clinical knowledge, to develop clinical reasoning and self-directed learning, and to promote an atmosphere that motivates learning. ${ }^{2}$ A survey of medical students at the University of Sydney identified three concepts that characterize PBL: 1) peer collaboration to develop clinical knowledge and reasoning; 2) independent learning; and 3) problemsolving. ${ }^{3}$ As a result of the structure and process of PBL, students have multiple roles. In addition to the traditional role of student, they are teachers to their peers, researchers of learning issues developed by the group, and providers of social support to other group members. ${ }^{4}$ Research advocates socialization of students to these goals and roles as a means to promote increased understanding and active engagement in the PBL process. ${ }^{1,3,5}$

Students find the perceived lack of explicitly defined content and assignments of the PBL process to be stressful. Determining the breadth and depth of material to be studied through self-directed learning and overlooking or missing important topics are common concerns. ${ }^{6}$ Students have identified three factors that promote learning in PBL: 1) tutor/facilitator, 2) group, and 3) self-directed

(c) The Internet Journal of Allied Health Sciences and Practice, 2016 
learning. ${ }^{7}$ According to focus groups and surveys of PBL students, an effective faculty facilitator is a guide rather than a teacher, one who creates a safe learning environment in which every member of the group is encouraged to participate. The effective facilitator intervenes appropriately to promote problem solving and metacognition, but does not lecture, interrupt with their own agenda, or dominate the group. $6,8,9$ Medical students noted that a good PBL group member is one who is self-motivated, wellprepared, actively participates, and is not rude, competitive, or domineering.6,9 Focus groups of medical students at McGill university described an effective small group as one that is non-threatening, adheres to the group's goals, encourages teamwork and individual participation, has an effective facilitator, and fosters problem-solving. ${ }^{9}$

To facilitate the transition from a traditional lecture-based setting to a small group PBL learning environment, physician assistant (PA) studies programs have incorporated opportunities to learn about PBL in their admissions process. ${ }^{10,11}$ Medical and nursing programs have utilized the Self-directed Learning Readiness Scale for Nursing Education (SDLRSNE) to assess students' likelihood of success with adult level independent learning environments. 12,13 However, the SDLRSNE was not found to be useful in differentiating readiness for PBL when administered to applicants of a graduate PA program. ${ }^{14}$ Part of the reason for this may be that the SDLRSNE does not contain items that assess important qualities of learning in a small group PBL setting. To rectify this area of concern, one group of educators developed pilot items pertaining to student expectations of the facilitator, expectations of self as related to the group, and expectations of others as related to the group. They found that these pilot items significantly changed on a pre-post questionnaire that was administered to PA applicants on the same occasion as the SDLRSNE.10,14 Therefore, it was determined that there is a need to develop a readiness questionnaire and scale specifically applicable to small group PBL education. The items in the questionnaire should include expectations about self-directed learning and small group process that reflect perceptions of PBL students regarding expectations of self, others, and the facilitator. The PBL readiness questionnaire used in this study was developed not only to assess applicant readiness, but also to assess changes in expectations and perceptions among PA program matriculants from the beginning to the end of the first didactic year. These changes reflect the students' process of incorporating goals and norms of PBL into their learning styles. It is hypothesized that graduate level PA students will incorporate attributes of small group PBL as they become proficient in the process and thus demonstrate significant change in their expectations of themselves, others, and the facilitator.

\section{METHODS}

\section{Participants}

Participants were 77 graduate students at the Chatham University PA program who matriculated in fall of 2013 (100\% of matriculants). Students who did not complete all items of the questionnaire at both beginning and end of semester administrations were excluded from the data analysis. There were 60 participants who completed the survey at both the beginning and end of the semester and had complete data at both time periods.

\section{Measures}

The authors developed the PBL Readiness Questionnaire, a 72-item 10-point Likert scale regarding student expectations of the PBL experience regarding self, others, and the facilitator. Two resources were used to develop questionnaire items. Students from the PA class of 2014 were surveyed at the end of the first year to identify critical qualities and expectations of self and others in a group as well as qualities of group members and effective facilitators in a group setting. The authors asked the following four questions: 1) What did you learn about the role of faculty in problem based learning; 2) What are your expectations of others in a PBL group; 3) What are your expectations of yourself in a PBL group; and 4) What do you think are the most important qualities of a good PBL participant. Responses to these questions were collated, and items were created based on the most frequently occurring responses for each question.

Another source of items was literature on characteristics associated with successful performance in a PBL setting such as cooperative learning, respect, communication skills, self-directed learning, reflection, and self-evaluation. ${ }^{15,16}$ The authors worded 58 of 71 items (82\%) in the direction such that high scores signified behaviors/attitudes consistent with readiness for working within a problem-based format, and the authors worded 13 of 71 items (18\%) in the opposite direction in order to avoid the affirmative bias. Items were categorized into subscales as either Expectations of Self (24 items), Expectations of Others (22 items), or Expectations of the Facilitator ( 25 items). One item which was inadvertently duplicated was eliminated from the analyses.

\section{Process}

The questionnaire was administered at the beginning of the first year fall semester and again at the end of the first year spring semester. Participation was voluntary and not associated with any aspect of course grade. Student names were on the original data, which were then de-identified by a staff member and assigned numerical codes in order to assure anonymity while still being able to compare data over time. The authors do not have access to the codes. No demographic or other identifying information

(C) The Internet Journal of Allied Health Sciences and Practice, 2016 
Effect of Two Semesters of Small Group Problem-Based Learning (PBL) On Expectations of Physician Assistant Students Regarding Self, Others,

were collected in order to assure anonymity of responses. Approval for the study was obtained from Chatham University's Institutional Review Board.

\section{Data Analysis}

Data were entered into Microsoft Excel 2010 and then migrated into SPSS 18 software, which was used for all data analyses. Data analyses included Multivariate Analyses of Variance (MANOVA) and Univariate Analyses of Variance (ANOVA).

\section{RESULTS}

These analyses reflect data on 60 participants who had complete data from both the beginning and end of the semester. Mean scores and standard deviations for each of the 71 questionnaire items appear in Table 1.

\section{Table 1. Means and Standard Deviations of Each Item}

\begin{tabular}{|c|c|c|c|}
\hline Item & Scale** & $\begin{array}{l}\text { Pre } \\
\text { Mean } \\
(S D+)\end{array}$ & $\begin{array}{l}\text { Post } \\
\text { Mean } \\
\text { (SD+) }\end{array}$ \\
\hline 1. I expect others to be respectful to all members of the group. & 0 & $\begin{array}{l}9.30 \\
(1.212)\end{array}$ & $\begin{array}{l}9.45 \\
(0.982)\end{array}$ \\
\hline 2. I expect to learn more on my own than from other group members. & $\mathrm{S}$ & $\begin{array}{l}4.47 \\
(2.182)\end{array}$ & $\begin{array}{l}6.34 \\
(2.037)\end{array}$ \\
\hline 3. I expect to remain an individual first and a group member second. & S & $\begin{array}{l}4.50 \\
(2.259)\end{array}$ & $\begin{array}{l}5.20 \\
(2.216)\end{array}$ \\
\hline 4. I expect to accommodate to others in the group. & $\mathrm{S}$ & $\begin{array}{l}8.48 \\
(1.479)\end{array}$ & $\begin{array}{l}8.70 \\
(1.169)\end{array}$ \\
\hline 5. I expect that I will contribute to the group's success. & S & $\begin{array}{l}9.05 \\
(1.064)\end{array}$ & $\begin{array}{l}9.27 \\
(0.918)\end{array}$ \\
\hline 6. I expect to keep frustrations with others to myself when participating in a group. ${ }^{*}$ & S & $\begin{array}{l}5.27 \\
(2.603)\end{array}$ & $\begin{array}{l}5.63 \\
(2.400)\end{array}$ \\
\hline 7. I expect to keep the group unaware of my frustrations with myself.. & $\mathrm{S}$ & $\begin{array}{l}6.13 \\
(2.213)\end{array}$ & $\begin{array}{l}5.82 \\
(2.439)\end{array}$ \\
\hline 8. I expect myself to work hard in the group. & S & $\begin{array}{l}9.68 \\
(0.676) \\
\end{array}$ & $\begin{array}{c}9.60 \\
(0.669) \\
\end{array}$ \\
\hline 9. I expect myself to come to group having completed my assignments. & $\mathrm{S}$ & $\begin{array}{l}9.65 \\
(0.685)\end{array}$ & $\begin{array}{l}9.65 \\
(0.577)\end{array}$ \\
\hline 10. I expect that I will work harder than others in the group. & S & $\begin{array}{l}6.10 \\
(2.275)\end{array}$ & $\begin{array}{l}6.62 \\
(2.195)\end{array}$ \\
\hline 11. I expect myself to support the group's goals. & S & $\begin{array}{l}9.20 \\
(1.447)\end{array}$ & $\begin{array}{l}9.10 \\
(0.951)\end{array}$ \\
\hline 12. I expect myself to focus on my own goals. & S & $\begin{array}{l}6.95 \\
(2.062)\end{array}$ & $\begin{array}{l}8.73 \\
(1.191)\end{array}$ \\
\hline 13. I expect myself to be patient with group members who want to move more slowly. & S & $\begin{array}{l}8.15 \\
(1.956)\end{array}$ & $\begin{array}{l}8.47 \\
(1.512) \\
\end{array}$ \\
\hline 14. I expect the group setting to motivate me to learn. & S & $\begin{array}{l}8.95 \\
(1.371)\end{array}$ & $\begin{array}{l}8.82 \\
(1.308)\end{array}$ \\
\hline 15. I expect myself to keep my level of motivation to learn high in the group. & S & $\begin{array}{l}9.17 \\
(0.977)\end{array}$ & $\begin{array}{l}9.13 \\
(0.947)\end{array}$ \\
\hline 16. I expect myself to keep pace with other members of the group. & S & $\begin{array}{l}8.35 \\
(1.338)\end{array}$ & $\begin{array}{l}8.65 \\
(1.527) \\
\end{array}$ \\
\hline 17. I expect to do my share of the work for the group. & S & $\begin{array}{l}9.67 \\
(0.629)\end{array}$ & $\begin{array}{l}9.52 \\
(1.157)\end{array}$ \\
\hline 18. I expect that it will be easy for me to contribute to group discussions. & S & $\begin{array}{l}7.25 \\
(1.762)\end{array}$ & $\begin{array}{l}8.13 \\
(1.692)\end{array}$ \\
\hline 19. I expect to complete my assignments for the group on time. & $\mathrm{S}$ & $\begin{array}{l}9.60 \\
(0.741)\end{array}$ & $\begin{array}{l}9.50 \\
(0.701)\end{array}$ \\
\hline
\end{tabular}


Effect of Two Semesters of Small Group Problem-Based Learning (PBL) On Expectations of Physician Assistant Students Regarding Self, Others,

\begin{tabular}{|c|c|c|c|}
\hline $\begin{array}{l}\text { 20. I expect to spend as much individual time as necessary to adequately complete my } \\
\text { group assignments. }\end{array}$ & S & $\begin{array}{l}8.25 \\
(2.191)\end{array}$ & $\begin{array}{l}8.67 \\
(1.336)\end{array}$ \\
\hline 21. I expect others will rate me as a good team member. & 0 & $\begin{array}{l}8.35 \\
(1.325)\end{array}$ & $\begin{array}{l}8.75 \\
(1.035)\end{array}$ \\
\hline 22. I expect that I will dominate group discussions. ${ }^{*}$ & S & $\begin{array}{l}7.47 \\
(1.961)\end{array}$ & $\begin{array}{l}7.48 \\
(2.021)\end{array}$ \\
\hline 23. I expect myself to be open to feedback from others in the group. & S & $\begin{array}{l}8.85 \\
(1.376)\end{array}$ & $\begin{array}{l}9.37 \\
(0.974)\end{array}$ \\
\hline 24. I expect group members to be respectful of all members in the group. & 0 & $\begin{array}{l}9.40 \\
(1.224)\end{array}$ & $\begin{array}{l}9.50 \\
(0.893)\end{array}$ \\
\hline \multicolumn{4}{|l|}{ 25. Item deleted as duplicate } \\
\hline 26. I expect all group members will freely contribute new information to the group. & 0 & $\begin{array}{l}8.12 \\
(1.823)\end{array}$ & $\begin{array}{l}8.98 \\
(1.186)\end{array}$ \\
\hline 27. I expect everyone to contribute to the group's success. & 0 & $\begin{array}{l}9.22 \\
(1.151)\end{array}$ & $\begin{array}{l}8.98 \\
(1.200)\end{array}$ \\
\hline 28. I expect others to freely share their frustrations about me in the group. & 0 & $\begin{array}{l}7.67 \\
(2.121)\end{array}$ & $\begin{array}{l}7.57 \\
(2.181)\end{array}$ \\
\hline 29. I expect others to freely share their frustrations with themselves in the group. & 0 & $\begin{array}{l}7.17 \\
(2.180)\end{array}$ & $\begin{array}{l}7.67 \\
(1.997)\end{array}$ \\
\hline 30. I expect other members of the group to maintain pace with the group. & 0 & $\begin{array}{l}7.27 \\
(2.224)\end{array}$ & $\begin{array}{l}7.37 \\
(1.886)\end{array}$ \\
\hline 31. I expect other members of the group to maintain pace with me. ${ }^{*}$ & 0 & $\begin{array}{l}6.28 \\
(2.001) \\
\end{array}$ & $\begin{array}{l}6.52 \\
(2.063) \\
\end{array}$ \\
\hline 32. I expect that others will easily contribute in group discussions. & 0 & $\begin{array}{l}7.38 \\
(1.878)\end{array}$ & $\begin{array}{l}7.90 \\
(1.591)\end{array}$ \\
\hline 33. I expect others to do their share of the work in the group. & 0 & $\begin{array}{l}9.32 \\
(0.965)\end{array}$ & $\begin{array}{l}9.33 \\
(0.795)\end{array}$ \\
\hline 34. I expect all group members to be hard workers. & 0 & $\begin{array}{l}8.95 \\
(1.333) \\
\end{array}$ & $\begin{array}{l}9.02 \\
(1.066) \\
\end{array}$ \\
\hline 35. I expect everyone to come to group having completed their assignments. & 0 & $\begin{array}{l}9.35 \\
(0.899) \\
\end{array}$ & $\begin{array}{l}9.30 \\
(0.850) \\
\end{array}$ \\
\hline 36. I expect others to work harder than I do in the group. ${ }^{*}$ & 0 & $\begin{array}{l}8.02 \\
(2.071)\end{array}$ & $\begin{array}{l}7.83 \\
(2.203)\end{array}$ \\
\hline 37. I expect others to support the group's goals. & 0 & $\begin{array}{l}8.77 \\
(1.566)\end{array}$ & $\begin{array}{l}8.88 \\
(1.091)\end{array}$ \\
\hline 38. I expect others to support my goals. & 0 & $\begin{array}{l}7.80 \\
(1.802)\end{array}$ & $\begin{array}{l}8.35 \\
(1.400) \\
\end{array}$ \\
\hline 39. I expect others to be patient with me when I want to move more slowly. & 0 & $\begin{array}{l}7.22 \\
(2.148) \\
\end{array}$ & $\begin{array}{l}7.60 \\
(1.950) \\
\end{array}$ \\
\hline $\begin{array}{l}\text { 40. I expect other group members to be patient with each other when some want to move } \\
\text { more slowly. }\end{array}$ & 0 & $\begin{array}{l}7.92 \\
(2.011)\end{array}$ & $\begin{array}{l}8.18 \\
(1.578)\end{array}$ \\
\hline 41. I expect the group setting to motivate others to learn. & 0 & $\begin{array}{l}8.92 \\
(1.344) \\
\end{array}$ & $\begin{array}{l}8.82 \\
(1.384) \\
\end{array}$ \\
\hline 42. I expect others to keep their level of motivation to learn high in the group. & 0 & $\begin{array}{l}8.90 \\
(1.145)\end{array}$ & $\begin{array}{l}8.88 \\
(1.106)\end{array}$ \\
\hline 43. I expect others to complete their assignments for the group on time. & 0 & $\begin{array}{l}9.23 \\
(1.170)\end{array}$ & $\begin{array}{l}9.27 \\
(1.006)\end{array}$ \\
\hline $\begin{array}{l}\text { 44. I expect others to spend as much individual time as necessary to complete adequately } \\
\text { their group assignments. }\end{array}$ & 0 & $\begin{array}{l}8.38 \\
(1.833) \\
\end{array}$ & $\begin{array}{l}8.47 \\
(1.308) \\
\end{array}$ \\
\hline 45. I expect that all others will be good team members. & 0 & $\begin{array}{l}7.73 \\
(2.154)\end{array}$ & $\begin{array}{l}8.07 \\
(2.024)\end{array}$ \\
\hline 46. I expect others in the group to be resistant to feedback from me. ${ }^{*}$ & 0 & $\begin{array}{l}7.02 \\
(2.244)\end{array}$ & $\begin{array}{l}8.07 \\
(2.098)\end{array}$ \\
\hline 47. I expect the facilitator to be respectful of all members of the group. & $\mathrm{F}$ & $\begin{array}{l}9.72 \\
(0.613) \\
\end{array}$ & $\begin{array}{l}9.65 \\
(0.606) \\
\end{array}$ \\
\hline
\end{tabular}


Effect of Two Semesters of Small Group Problem-Based Learning (PBL) On Expectations of Physician Assistant Students Regarding Self, Others,

\begin{tabular}{|c|c|c|c|}
\hline $\begin{array}{l}\text { 48. I expect facilitators to keep frustrations with others to themselves when facilitating the } \\
\text { group.* }\end{array}$ & $\mathrm{F}$ & $\begin{array}{l}4.50 \\
(2.813)\end{array}$ & $\begin{array}{l}4.35 \\
(2.654)\end{array}$ \\
\hline 49. I expect facilitators to keep the group unaware of their frustrations with themselves. & $\mathrm{F}$ & $\begin{array}{l}4.60 \\
(2.519)\end{array}$ & $\begin{array}{l}4.88 \\
(2.811)\end{array}$ \\
\hline 50. I expect facilitators to have a plan for each session. & $\mathrm{F}$ & $\begin{array}{l}5.57 \\
(2.445)\end{array}$ & $\begin{array}{l}6.52 \\
(2.508)\end{array}$ \\
\hline 51. I expect the facilitator to challenge me at every session. & $\mathrm{F}$ & $\begin{array}{l}8.45 \\
(1.731)\end{array}$ & $\begin{array}{l}9.20 \\
(0.917)\end{array}$ \\
\hline 52. I expect the facilitator to support the group's goals. & $\mathrm{F}$ & $\begin{array}{l}8.55 \\
(1.294)\end{array}$ & $\begin{array}{l}9.10 \\
(1.175)\end{array}$ \\
\hline 53. I expect the facilitator to be patient when I am slow to understand a concept. & $\mathrm{F}$ & $\begin{array}{l}7.85 \\
(2.082)\end{array}$ & $\begin{array}{l}8.38 \\
(1.519)\end{array}$ \\
\hline 54. I expect the facilitator to push other group members when they are moving too slowly. & $\mathrm{F}$ & $\begin{array}{ll}5.32 \\
(2.151) \\
\end{array}$ & $\begin{array}{l}5.28 \\
(2.408) \\
\end{array}$ \\
\hline 55. I expect the facilitator to set the pace of learning in the group. & $\mathrm{F}$ & $\begin{array}{l}4.58 \\
(2.619)\end{array}$ & $\begin{array}{l}5.35 \\
(2.392)\end{array}$ \\
\hline 56. I expect the facilitator to teach more than to guide. ${ }^{*}$ & $\mathrm{~F}$ & $\begin{array}{l}8.12 \\
(1.833)\end{array}$ & $\begin{array}{l}8.10 \\
(2.072)\end{array}$ \\
\hline 57. I expect different facilitators to provide a similar group experience. & $\mathrm{F}$ & $\begin{array}{l}6.23 \\
(2.431)\end{array}$ & $\begin{array}{l}6.73 \\
(2.544)\end{array}$ \\
\hline 58. I expect the facilitator to assist me in identifying areas for further study. & $\mathrm{F}$ & $\begin{array}{l}6.65 \\
(2.483)\end{array}$ & $\begin{array}{l}8.67 \\
(1.674)\end{array}$ \\
\hline 59. I expect the facilitator to provide feedback about my strengths and weaknesses. & $\mathrm{F}$ & $\begin{array}{l}9.10 \\
(1.020)\end{array}$ & $\begin{array}{l}9.40 \\
(0.924)\end{array}$ \\
\hline 60. I expect the facilitator to focus on the knowledge base rather than the group process. & $\mathrm{F}$ & $\begin{array}{l}4.72 \\
(2.051)\end{array}$ & $\begin{array}{l}6.28 \\
(2.218)\end{array}$ \\
\hline $\begin{array}{l}\text { 61. I expect the facilitator to continue to ask questions about a topic when the group has } \\
\text { already identified that topic as requiring further study. }\end{array}$ & $\mathrm{F}$ & $\begin{array}{l}4.88 \\
(2.585)\end{array}$ & $\begin{array}{l}7.97 \\
(2.421)\end{array}$ \\
\hline 62. I expect the facilitator to limit the number of questions that they ask. ${ }^{*}$ & $\mathrm{~F}$ & $\begin{array}{l}7.42 \\
(2.142)\end{array}$ & $\begin{array}{l}7.65 \\
(2.298)\end{array}$ \\
\hline 63. I expect facilitator to foster self-directed learning during group sessions. & $\mathrm{F}$ & $\begin{array}{l}8.55 \\
(1.872)\end{array}$ & $\begin{array}{l}8.68 \\
(1.347)\end{array}$ \\
\hline 64. I expect the facilitator to lead the group sessions. ${ }^{*}$ & $\mathrm{~F}$ & $\begin{array}{l}7.02 \\
(2.311)\end{array}$ & $\begin{array}{l}7.02 \\
(2.404)\end{array}$ \\
\hline 65. I expect the facilitator to encourage us to rely on each other rather than on him or her. & $\mathrm{F}$ & $\begin{array}{l}9.00 \\
(1.042)\end{array}$ & $\begin{array}{l}8.53 \\
(1.702)\end{array}$ \\
\hline 66. I expect the facilitator to provide clinically relevant stories during group sessions. & $\mathrm{F}$ & $\begin{array}{l}7.08 \\
(2.619)\end{array}$ & $\begin{array}{l}7.52 \\
(1.987)\end{array}$ \\
\hline 67. I expect the facilitator to tell me exactly what I need to know. ${ }^{*}$ & $\mathrm{~F}$ & $\begin{array}{l}8.25 \\
(2.136) \\
\end{array}$ & $\begin{array}{l}7.63 \\
(2.477) \\
\end{array}$ \\
\hline 68. I expect the facilitator to help me identify the limits of my knowledge. & $\mathrm{F}$ & $\begin{array}{l}7.28 \\
(2.100)\end{array}$ & $\begin{array}{l}9.07 \\
(1.191)\end{array}$ \\
\hline 69. I expect the facilitator to encourage me to rely on their expertise. ${ }^{*}$ & F & $\begin{array}{l}6.42 \\
(2.657)\end{array}$ & $\begin{array}{l}6.75 \\
(2.685)\end{array}$ \\
\hline 70. I expect the facilitator to be open to feedback. & $\mathrm{F}$ & $\begin{array}{l}8.63 \\
(1.288)\end{array}$ & $\begin{array}{l}9.28 \\
(0.904)\end{array}$ \\
\hline 71. I expect to contribute as much as others to the group. & S & $\begin{array}{l}9.20 \\
(1.176)\end{array}$ & $\begin{array}{l}9.07 \\
(1.219)\end{array}$ \\
\hline 72. I expect the facilitator to tell me when I am wrong. ${ }^{*}$ & $\mathrm{~F}$ & $\begin{array}{l}5.77 \\
(3.280)\end{array}$ & $\begin{array}{l}6.48 \\
(3.213)\end{array}$ \\
\hline $\begin{array}{l}{ }^{*} \text { Denotes reverse coding of item } \\
{ }^{* *} \mathrm{~S}=\text { subscale Expectations of Self } \\
{ }^{* *} \mathrm{O}=\text { subscale Expectations of Others } \\
{ }^{* *} \mathrm{~F}=\text { subscale Expectations of Facilitator }\end{array}$ & & & \\
\hline
\end{tabular}


Items worded in a negative direction were reverse-scored to ensure that high scores reflected high readiness for working in a small group problem-based learning environment. A total score was computed by adding all items together. Three sub-scales were computed to measure (a) Expectations of Self, (b) Expectations of Others, and (c) Expectations of Facilitators. Repeated measures univariate ANOVA on total score revealed a significant pre-post effect, $F(1,59)=5.88, p=.018$. Posttest score mean (565.02) was significantly higher than pretest score mean (552.37). A repeated measures MANOVA with time (pre and posttest) as the independent variable and the three subscales (Expectations of Self, Expectations of Others, and Expectations of Facilitators) as the dependent variables yielded a significant effect of time, multivariate $F(3,57)=3.48, p=.022$. We then computed univariate ANOVAs on each of the three subscales. Both Expectations of Facilitators and Expectations of Others changed significantly, with Expectations of Others approaching significance (see Table 2).

Table 2. Subscale and Total Score

\begin{tabular}{|c|c|c|c|c|}
\hline Scale & $\begin{array}{c}\text { Pre Mean (SD+) } \\
\text { [Per item average] }\end{array}$ & $\begin{array}{c}\text { Post Mean (SD+) } \\
\text { [Per item average] }\end{array}$ & $\mathrm{F}$ & $\mathbf{P}$ \\
\hline $\begin{array}{l}\text { Expectations of Self } \\
\text { ( } 22 \text { items) }\end{array}$ & $\begin{array}{l}174.38(11.60) \\
{[7.93]}\end{array}$ & $\begin{array}{l}181.57(11.64) \\
{[8.25]}\end{array}$ & 19.68 & .000 \\
\hline $\begin{array}{l}\text { Expectations of Others } \\
\text { ( } 24 \text { items) }\end{array}$ & $\begin{array}{l}197.67(20.88) \\
{[8.24]}\end{array}$ & $\begin{array}{l}202.75(18.55) \\
{[8.45]}\end{array}$ & 3.40 & .070 \\
\hline $\begin{array}{l}\text { Expectations of Facilitator } \\
\text { ( } 25 \text { items) }\end{array}$ & $\begin{array}{l}174.25(10.93) \\
{[6.97]}\end{array}$ & $\begin{array}{l}188.48(11.95) \\
{[7.54]}\end{array}$ & 59.82 & .000 \\
\hline Total & 546.30 & 572.80 & 34.64 & .000 \\
\hline
\end{tabular}

The change from pre to posttest for each of the subscales was computed for each participant. The number of participants that evidenced increased scores exceeded the number of participants that had decreased scores or that stayed the same. Although this is not surprising given the MANOVA and ANOVA results, it does provide support for the validity of this measure and indicates that the majority of students changed their views in the expected and desired direction from pre to posttest involvement with the PBL group. Not surprisingly, this change was most prominent for Expectations of Facilitator.

\begin{tabular}{|l|c|c|c|c|c|}
\hline \multicolumn{1}{|c|}{ Variable } & $\begin{array}{c}\text { Mean } \\
\text { (Standard } \\
\text { Deviation+) }\end{array}$ & $\begin{array}{c}\text { Low Score } \\
\text { High } \\
\text { Score } \\
\text { Range }\end{array}$ & $\begin{array}{c}\text { Number } \\
\text { (percentage) } \\
\text { that decreased }\end{array}$ & $\begin{array}{c}\text { Number (percentage) } \\
\text { that stayed the same }\end{array}$ & $\begin{array}{c}\text { Number } \\
\text { (percentage) } \\
\text { that increased }\end{array}$ \\
\hline $\begin{array}{l}\text { Expectations of } \\
\text { Self }\end{array}$ & 7.18 & -18 & 15 & 3 & 42 \\
& $(12.54)$ & 39 & $(25.00 \%)$ & $(5.00 \%)$ & $(70.00 \%)$ \\
\hline Expectations of & 5.08 & -45 & 22 & 2 & 36 \\
Others & $(21.36)$ & 57 & $(36.67 \%)$ & $(3.33 \%)$ & $(60.00 \%)$ \\
\hline Expectations of & 14.23 & -30 & 8 & 1 & 51 \\
Facilitator & $(14.25)$ & 55 & $(13.33 \%)$ & $(1.67 \%)$ & $(85.00 \%)$ \\
\hline
\end{tabular}

\section{DISCUSSION}

Results of data analysis suggest that after 9 months of participation in PBL, total score of students' responses changed significantly in the direction of characteristics that previous research has indicated students associate with good group members and good facilitators. $3,4,6$ The significant change in Expectations of Facilitator may have occurred because the pedagogy represents a novel experience for students. Although students may have done work previously in group settings, they may not have experienced faculty in the role of facilitator rather than teacher. Although they may have observed a PBL session or read about PBL prior to matriculation, $\mathrm{PBL}$ is an experiential process, requiring participation to fully understand how it differs from the traditional classroom setting. The emphasis in PBL is on student-centered learning rather than teacher-centered instruction. PBL participation may challenge students to alter their schema for knowledge acquisition. Instead of relying on faculty to provide information, students are probed with questions. These questions are formulated to stimulate their interest in a topic, which then promotes self-directed learning and understanding through group discussion. ${ }^{17}$ After 9 months of PBL, students appear to change their expectations of the facilitator. The change score for the three subscales indicates that the greatest change was in the subscale of Expectations of Facilitator, where $85 \%$ of participants increased their scores regarding those expectations. 
Regarding students' change in Expectations of Self, although students may have had experience with group projects in other courses, they might not have worked with the level of interdependence required in a PBL setting. The significant positive change in Expectations of Self could indicate that students do not have accurate expectations of their own role in this type of group setting, and the experience of participating in PBL may positively affect Expectations of Self. The change score for the three subscales indicates that the majority of participants $(70 \%)$ changed Expectations of Self in a positive direction from pre to posttest. This change may be the result of improved skills in self-evaluation and self-reflection leading to change in self-directed learning behaviors. This is consistent with recent trends towards encouraging health professions students to engage in self-evaluation and self-reflection. ${ }^{18}$

With regards to Expectations of Others, the nature of PBL requires that students rely more on other group members for information than is true in a lecture-based setting. ${ }^{19}$ Although the Analysis of Variance only approached significance, the change score for Expectations of Others indicates that the majority of participants $(60 \%)$ did change in a positive direction from pre to posttest. The lack of significance on Analysis of Variance for Expectations of Others may be accounted for by a ceiling effect because pretest scores were already high. Also, there was a high standard deviation and range of scores for this subgroup, which does indicate a wider spectrum of responses regarding Expectations of Others versus Expectations of Self or Expectations of Facilitator and which decreases the likelihood of finding significant differences. This variance can be accounted for by the number of participants whose scores increased on the Expectations of Others subscale from pre to posttest plus participants whose scores decreased on the Expectations of Others subscale from pre to posttest. This subscale had the highest percentage of participants whose scores decreased from pre to posttest.

The subscale Expectation of Others had a large range and a large percentage of subjects whose scores decreased from pre to posttest as well as a large percentage who increased pre to posttest. This may indicate that there are two subgroups of students, one for whom the PBL experience enhances their appreciation of others on a team and another for whom the PBL experience detracts from their appreciation of the role of others on the team. For students whose appreciation of others is enhanced, this may translate into positive expectations of others as an enduring quality at the team level when transitioning to their professional role. In addition, group members may be invested in positive expectations of others in the group since they are depending on the quality of others' self-directed learning for their own knowledge acquisition.

This positive expectation of others on a team could benefit clinical practice, whether interprofessional or within their profession. This has implications for developing professionals who will be expected to work on teams and will need to be able to recognize the role that others play in enhancing their group experience, and eventually, performance on a team. One explanation for those students whose scores did not improve or were lower than initial scores could reflect participants who were disappointed by the performance of some other students in the class, therefore lowering their expectations of others in the PBL setting. Not every student adapts quickly and easily to PBL, and students who are impatient with the growth of others could be annoyed. This may reflect a lack of respect for others' input and could indicate students who may not be good team members. This is consistent with a paper (IPE) which indicated that PA students had less readiness for interprofessional learning than other health professions students. ${ }^{20}$ Being able to identify such students through use of this tool might enable intervention to increase students' appreciation for the input of other professions.

One possible confounding factor is variability in the preceding PBL experience of the participants. Some students may have participated in undergraduate PBL experiences which could have influenced their expectations, while others may not have had such experiences. Students varied in their work experiences as well, some of which may have included team experiences which could have influenced their expectations of self and others. Another possible confounding factor is the decision to have both positively and negatively worded items to avoid the affirmative bias. Some items could be viewed as positive or negative depending on the pedagogical viewpoint of the researcher who might utilize the tool. Gender differences were not examined as part of this study, but there may be a significant difference in expectations of self and others based on gender.

An area for future study would be a psychometric analysis of the questionnaire items in order to refine the tool and ascertain the reliability and validity of items and subscales. Other future studies should examine whether initial scores on this questionnaire correlate with program measures such as PBL evaluations, other evaluative tools such as multiple choice question (MCQ) examinations, clinical evaluations, or national examinations. If such correlations can be demonstrated, then this tool could be used by any program using PBL as a pedagogical method for admissions purposes, not necessarily for inclusion/exclusion, but to provide appropriate structured support of student success.

\section{REFERENCES}

1. Bate E, Taylor DCM. Twelve Tips on how to survive PBL as a medical student. Med Teach. 2013;35:95-100. [PMID: 24295273] 
2. Onyon C. Problem-based learning: a review of the educational and psychological theory. The Clinical Teacher. 2012;9:22-6. [PMID: 22225888]

3. Hendry GD, Lyon PM, Prosser M, Size D. Conceptions of problem-based learning: the perspectives of students entering a problem-based medical program. Med Teach. 2006;6:573-75. [PMID: 17074711]

4. Hammel J, Royeen CB, Bagatell N, Chandler B, Jensen G, Loveland J, et al. Student perspectives on problem-based learning in an occupational therapy curriculum: a multiyear qualitative evaluation. Am J Occupational Ther. 1999;53(2):199-206. [PMID: 10200843]

5. Prosser M, Sze D. Problem-based learning: student learning experiences and outcomes. Clinical Linguistics \& Phonetics. 2014;28(1-2):131-42. [PMID: 23944271]

6. Maudsley G, Williams EMI, Taylor DCM. Problem-based learning at the receiving end: A 'mixed methods' study of junior medical students' perspectives. Adv in Health Sci Educ. 2008;13:435-51. [PMID: 17285251]

7. Caplow JA, Donaldson JF, Kardash C, Hosokawa M. Learning in a problem-based medical curriculum: students' conceptions. Med Ed. 1997;31:440-7. [PMID: 9463647]

8. Schmidt HG, Togans JI, Yew EHJ. The process of problem-based learning: what works and why. Med Ed. 2011;45:792-806. [PMID: 21752076]

9. Steinhert Y. Student perceptions of effective small group teaching. Med Ed. 2004;38:286-293. [PMID: 14996338]

10. Hawkins S, Hertweck M, Goreczny AJ, Laird J. Student expectations of problem-based learning (PBL). Med Teach. 2013 Jun;35(6):525. [PMID: 23464897]

11. Midla GS, Coryell JE. Problem-based learning preparation for physician assistant faculty. The U.S. Army Medical Department Journal. 2010;10:39-47. [PMID: 21181673]

12. Fisher $\mathrm{M}$, King J. The self-directed learning readiness scale for nursing education revisited: A confirmatory factor analysis. Nurse Education Today. 2010;30:44-8. [PMID: 19541394]

13. Hendry G, Ginns P. Readiness for self-directed learning: Validation of a new scale with medical students. Med Teach. 2009;31:918-20. [PMID: 19877864]

14. Hawkins S, Hertweck M, Laird J, Goreczny AJ. Problem-based learning readiness: Evaluation of physician assistant readiness for group learning. International J Med Pharmacy. 2013;1(1):14-21.

15. Chamberlain SE, Searle J. Assessing suitability for a problem-based learning curriculum: Evaluating a new student selection instrument. Med Ed. 2005;39:250-7. [PMID: 15733160]

16. Novak S, Shah S, Wilson JP, Lawson KA, Salzman RD. Pharmacy students' learning styles before and after a problem-based learning experience. J Pharmaceutical Ed. 2006;70:1-8. [PMID: 17136193]

17. Barrows HS. Practice Based Learning: Problem-Based Learning Applied to Medical Education. Springfield, Illinois: Southern Illinois University School of Medicine; 1994.

18. Butani L, Blankenburg R, Long M. Stimulating reflective practice among your learners. Pediatrics. 2013;131:204-6. [PMID: 23339227]

19. Barrows HS. The Tutorial Process. Springfield, Illinois: Southern Illinois University School of Medicine; 1988.

20. Hertweck ML, Hawkins SR, Bednarek ML, Goreczny AJ, Schreiber JL, Sterrett SE. Attitudes toward interprofessional education: comparing physician assistant and other healthcare students. JPAE. 2012:23(2):8-15. [PMID: 22827145] 